\title{
Perceived exercise benefits and barriers among power wheelchair soccer players
}

\author{
J. P. Barfield, DA; ${ }^{{ }^{*}}$ Laurie A. Malone, PhD $^{2}$ \\ ${ }^{1}$ Department of Exercise Science, Physical Education, and Wellness, Tennessee Tech University, Cookeville, TN; \\ ${ }^{2}$ Research and Education, Lakeshore Foundation, Birmingham, $A L$
}

\begin{abstract}
Lack of exercise is a major risk factor for secondary conditions among persons dependent upon motorized wheelchairs. Power wheelchair soccer is a unique exercise opportunity for this population, and understanding factors that influence exercise decision-making is necessary for clinicians to help those in motorized chairs reduce their secondary risk. Therefore, this study examined differences in perceived benefits and barriers to exercise among power wheelchair soccer players using a mixed-methods analysis. The most common perceived benefit to exercise was "Exercising lets me have contact with friends and persons I enjoy." Post hoc comparisons of quantitative data indicated that persons with muscular dystrophy perceived exercise to be significantly less important than did other disability groups $(p<0.05)$. "Exercise is hard work for me," "Exercise tires me," and "There are too few places for me to exercise" were the most common perceived barriers. These findings can assist with development of exercise opportunities for power wheelchair users.
\end{abstract}

Key words: disability sport, environmental barriers, multiple sclerosis, physical disability, rehabilitation, social barriers, social cognitive theory, spinal cord injury, therapeutic exercise, traumatic brain injury.

\section{INTRODUCTION}

Regular exercise is associated with multiple positive health outcomes among persons with physical disabilities. Specifically, a lifestyle that includes regular exercise has been shown to improve quality of life and reduce risk of secondary conditions associated with disability, such as obesity, depression, and pain [1]. Persons with physical disabilities are less active than the general population and therefore less likely to gain associated health benefits [2-4]. Mobility is a major exercise issue within this population - many depend upon wheelchairs to engage in sport and recreation (e.g., persons with cerebral palsy $[\mathrm{CP}]$ or muscular dystrophy [MD]). Fortunately, wheelchair sport can provide meaningful exercise opportunities. This option is a growing component of rehabilitation and postrehabilitation services for persons with physical disabilities and chronic conditions [5-7].

Wheelchair sport results in important benefits in the cognitive, psychomotor, and affective domains. Di Russo and others have reported that open-skill wheelchair sports enhance executive processing skills needed for everyday function [8]. Psychomotor benefits of wheelchair sport include improved fitness [9-12] and wheelchair mobility [13-14]. These improvements are not surprising, given that energy expenditure in various wheelchair sports is sufficient for health-related benefits and can be as high as five times resting rates [15-17]. Affective outcomes might constitute the most important

Abbreviations: $\mathrm{CP}=$ cerebral palsy, $\mathrm{EBBS}=$ Exercise Benefits and Barriers Scale, MD = muscular dystrophy.

*Address all correspondence to J. P. Barfield, DA; School of Sport Science, 376 Hale St, Endicott College, Beverly, MA 01945; 978-232-5210; fax: 978-232-2600.

Email: barfield@endicott.edu

http://dx.doi.org/10.1682/JRRD.2011.12.0234 
benefit, however. In a study of veteran wheelchair games attendees, participants reported that sport enhanced their personal relationships, social interactions, self-care skills, and acceptance of disability [14]. Improved quality of life and affect are important outcomes of any rehabilitation or exercise intervention and have been consistently reported across multiple wheelchair sport settings [9,18-21].

Although wheelchair sport is an option for many persons with physical disabilities, those with the highest levels of functional impairment have fewer disability sport options and therefore are at greater risk for reduced exercise and associated secondary conditions [22-23]. Power wheelchair soccer was the first sport developed for persons requiring electric rather than manual wheelchairs. It is an increasingly popular exercise option for persons with high levels of impairment $[22,24]$. Although little research has addressed outcomes of power soccer participation, limited empirical data support similar psychomotor and affective benefits as disability sport in general. Barfield and colleagues noted that 71 percent of power wheelchair soccer players with $\mathrm{CP}$ or MD sustained an exercise intensity of 55 percent of peak heart rate for more than 30 min during power wheelchair soccer competition [25]. This intensity is associated with healthrelated fitness improvement. Additionally, Kumar and colleagues noted greater community interaction among power wheelchair users who participated in veteran wheelchair games compared with nonparticipants [22]. To increase the number of persons benefiting, however, researchers must understand factors that encourage or discourage exercise within this population.

\section{RESEARCH PROBLEM}

Despite the potential benefits of power wheelchair soccer, factors influencing exercise in this population are undocumented. To encourage exercise, multiple authors have called for examination of perceived exercise influences in homogeneous samples of distinct disability groups [26-28]. Power soccer players are a distinct group with greater barriers to exercise because of greater levels of impairment $[23,29]$. The primary purpose of this study was to examine the perceived benefits and barriers to exercise among power wheelchair soccer players. Because physical and environmental factors can affect how persons with physical disabilities perceive experiences [30], we examined benefits and barriers within power soccer play- ers as a whole and across demographic groups when significant quantitative differences were found.

\section{METHODS}

\section{Participants}

Participants were recruited from a national power wheelchair soccer competition. This recruitment method was chosen to identify a nationally representative, demographically robust cohort. All methods were approved by the Emory and Henry College Institutional Review Board before data collection, and all participants provided informed consent.

\section{Procedures}

The power soccer tournament director and individual team coaches were contacted about the study before a national event. Coaches asked athletes whether they were interested in participating. If an individual expressed interest, he or she completed an informed consent form, a brief demographic survey, and the Exercise Benefits and Barriers Scale (EBBS) at the tournament. Score sheets were collected by the tournament director so that researchers could not influence or direct participant responses.

\section{Instrument}

The EBBS produces three numeric scores (total, benefits, barriers) and allows for reflection on 43 personal and environmental items, thereby providing researchers with both qualitative and quantitative data (Figure 1). Each statement is scored in a 4-item, forced-choice Likert format, in which 1 indicates "strongly disagree" and 4 indicates "strongly agree." When the instrument is used as a whole, the possible range of scores is 43 to 172 , with higher scores indicating a more favorable perception of exercise relative to perceived barriers. The possible range of scores on the benefits scale is 29 to 116 , and on the barriers scale is 14 to 56 , with higher scores indicating greater perceived benefits or barriers to exercise, respectively. Acceptable reliability and construct validity of the instrument have been reported [31-32].

\section{Analyses}

We used a mixed-methods analysis to examine perceptions among power soccer players. To examine qualitative responses, we recorded the three highest-ranked 


\begin{tabular}{|c|c|c|}
\hline Factor & \multicolumn{2}{|c|}{ Exercise Benefit Statements } \\
\hline Environmental & $\begin{array}{l}\text { Exercise is good entertainment for me. } \\
\text { Exercise improves the quality of my work. } \\
\text { Exercising lets me have contact with friends } \\
\text { and persons } \\
\text { I enjoy. }\end{array}$ & $\begin{array}{l}\text { Exercising is a good way for me to meet people. } \\
\text { Exercising increases my acceptance by others. }\end{array}$ \\
\hline Personal & $\begin{array}{l}\text { Exercising takes too much of my time. } \\
\text { Exercise is hard work for me. } \\
\text { I think people in exercise clothes look funny. }\end{array}$ & $\begin{array}{l}\text { I am too embarrassed to exercise. } \\
\text { Exercise tires me. } \\
\text { I am fatigued by exercise. }\end{array}$ \\
\hline Environmental & $\begin{array}{l}\text { Places for me to exercise are too far away. } \\
\text { It costs too much to exercise. } \\
\text { My significant other does not encourage exercise. } \\
\text { Exercise takes too much time from my family } \\
\text { responsibilities. }\end{array}$ & $\begin{array}{l}\text { Exercise facilities do not have convenient schedules for me. } \\
\text { There are too few places for me to exercise. } \\
\text { Exercise takes too much time from family relationships. } \\
\text { My family members do not encourage me to exercise. }\end{array}$ \\
\hline
\end{tabular}

Figure 1.

Benefit and barrier items on Exercise Benefits and Barriers Scale.

benefits and barriers for the entire cohort. Items were listed in order of influence, and additional items were listed when ties were present. To examine quantitative distinctions, we used Kruksal-Wallis nonparametric tests to compare median EBBS total, EBBS benefit, and EBBS barrier scores by disability type (CP, MD, or other), age (18-29 yr or $\geq 30 \mathrm{yr}$ ), sex, power wheelchair soccer experience ( $\leq 1 \mathrm{yr}, 2-4 \mathrm{yr}$, or $\geq 5 \mathrm{yr})$, and disability sport experience ( $\leq 2.5 \mathrm{yr}, 3-9 \mathrm{yr}$, or $\geq 10 \mathrm{yr}$ ). When significant differences were detected among group medians $(p<0.05)$, qualitative responses were reexamined within corresponding demographic groups.

\section{RESULTS}

We enrolled a total of 25 participants. Their mean age was $28.8 \pm 9.2 \mathrm{yr}$; they were an average $163.7 \pm 11.5 \mathrm{~cm}$ tall, weighed an average $61.8 \pm 17.8 \mathrm{~kg}$, and had an average of $3.2 \pm 2.5 \mathrm{yr}$ of power soccer experience. Most participants were male (76\%) and Caucasian (76\%). Three participants were college graduates, with another nine (36\%) having some college education. The remaining 13 (52\%) completed high school but did not attend college. Participants consisted of individuals with CP $(n=13)$, MD $(n=5)$, and other physical disabilities that included multiple sclerosis, spinal cord injury, and traumatic brain injury $(n=7)$.

For the cohort as a whole, participants reported both personal and environmental influences as primary benefits to exercise (Figure 2). "Exercising lets me have contact with friends and persons I enjoy" was the most important perceived benefit, and this item was consistent across most demographic groups. Median EBBS total and EBBS benefit scores differed significantly among disability groups (Table), specifically because persons with $\mathrm{CP}$ and other physical disabilities perceived exercise to be significantly more important than did persons with MD $(p<0.05)$. Median EBBS total and EBBS benefit scores were not significantly different for age, sex, or playing experience. Specific to perceived exercise barriers, "Exercise is hard work for me" and "Exercise tires 
JRRD, Volume 50, Number 2, 2013

\begin{tabular}{|c|c|}
\hline Benefit Statement & Factor \\
\hline $\begin{array}{l}\text { Exercising lets me have contact with friends and } \\
\text { persons I enjoy. }\end{array}$ & Environmental \\
\hline enjoy exercise. & Personal \\
\hline Exercise improves my mental health. & Personal \\
\hline $\begin{array}{l}\text { Exercising is a good way for me to meet new peo- } \\
\text { ple. }\end{array}$ & Environmental \\
\hline Exercise is good entertainment for me. & Environmental \\
\hline Barrier Statement & Factor \\
\hline Exercise is hard work for me. & Personal \\
\hline Exercise tires me. & Personal \\
\hline There are too few places for me to exercise. & Environmental \\
\hline
\end{tabular}

Figure 2.

Perceived benefits and barriers of entire cohort $(N=25)$. Statements represent top three ranked perceptions (additional items represent ties). "Tied items.

me" were the highest ranked barriers for the entire cohort. Median EBBS barrier scores did not differ significantly among demographic groups, indicating that disability type, age, sex, and playing experience did not affect barrier rankings.

\section{DISCUSSION}

\section{Exercise Benefits}

Individuals who play power wheelchair soccer perceived the primary benefit to be "Exercising lets me have contact with friends and persons I enjoy." This outcome is consistent with the literature reporting the positive environmental influence of social support among multiple populations with physical disabilities [33-35] and the general population [32]. Our cohort also reported personal benefit factors such as "I enjoy exercise" and "Exercise improves my mental health." These perceived benefits are consistent with motivation and attitude factors reported for persons with [26,36] and without [37] physical disabilities.
However, "Exercising improves my self-concept," the EBBS item most similar to self-efficacy, was not perceived as important by power wheelchair soccer players. Self-efficacy reflects an individual's perceived competence in a given behavior and is a typical exercise influence for persons with [38] and without [39] physical disabilities. The absence of this influence in the current sample could be due to the dynamics of the active cohort. Sport participants might have high levels of exercise selfefficacy and thus would not perceive the same benefit of exercise in this regard. If this assumption is accurate, sport participants may have already overcome any initial trepidation about trying exercise, and other factors have become more important to their continued exercise participation. This rationale fits with the reports of Cardinal and others indicating that decisional pros, or reasons to exercise, outweigh decisional cons among regular exercisers (e.g., current sport participants) [39]. However, alternative personal benefits (e.g., contact with friends, meeting new people, improving mental health) simply might be most important to power wheelchair users, a group with few opportunities for activity. This possibility seems realistic if one considers that the cohort reported only social and psychological factors, not other benefits typically reported in exercise literature (e.g., physical performance gains, life enhancement).

It is also important to note that perceived benefits varied by disability type. Inconsistent with the primarily attitudinal influences reported for many persons with physical disabilities $[26,33,36]$, power wheelchair soccer players with $\mathrm{CP}$ perceived several physical outcome benefits, including improvement of muscle tone and cardiovascular functioning (Figure 3). However, persons with MD reported social interaction as the primary benefit of exercise. The importance of social interaction has been noted for multiple disability groups $[34,36,40]$, but the focus on one particular benefit factor is unique to the lit-

Table.

Exercise Benefits and Barriers Scale (EBBS) scores by disability type.

\begin{tabular}{lccccc}
\hline \multicolumn{1}{c}{ EBBS Score } & $\begin{array}{c}\text { Cerebral Palsy } \\
(\boldsymbol{n}=\mathbf{1 3})\end{array}$ & $\begin{array}{c}\text { Muscular Dystrophy } \\
(\boldsymbol{n}=\mathbf{5})\end{array}$ & $\begin{array}{c}\text { Other } \\
(\boldsymbol{n}=\mathbf{7})\end{array}$ & $\boldsymbol{\chi}^{\mathbf{2}}$ & $\boldsymbol{p}$-Value \\
\hline Total & $140 \pm 13$ & $118 \pm 9$ & $145 \pm 15$ & 8.78 \\
Benefit & $99 \pm 11$ & $79 \pm 7$ & $101 \pm 12$ & 9.01 \\
Barrier & $42 \pm 6$ & $40 \pm 2$ & $44 \pm 5$ & 0.009 \\
\hline
\end{tabular}

Note: EBBS total scores range from 43 to 172, with higher scores reflecting more favorable perception of exercise relative to perceived barriers. Benefit scores range from 29 to 116 and barrier scores range from 14 to 56, with higher scores reflecting greater benefit or barrier, respectively. 
BARFIELD and MALONE. Perceived exercise benefits

\begin{tabular}{|c|c|c|}
\hline $\begin{array}{l}\text { Participants with } \\
\text { Cerebral Palsy } \\
(n=13)\end{array}$ & $\begin{array}{l}\text { Participants with } \\
\text { Muscular Dystrophy } \\
(n=5)\end{array}$ & $\begin{array}{l}\text { Other } \\
(n=7)\end{array}$ \\
\hline $\begin{array}{l}\text { Exercising lets me have contact with friends and persons I enjoy. } \\
\text { ×My muscle tone is improved with exercise. } \\
\text { *I will live longer if I exercise. } \\
\text { * } M y \text { physical endurance is improved by exercising. } \\
\text { *I have improved feelings of well-being from exercise. } \\
\text { I }\end{array}$ & $\begin{array}{l}\text { Exercise is good entertainment for me. } \\
\text { Exercising is a good way for me to meet new } \\
\text { people. } \\
\text { Exercising lets me have contact with friends and } \\
\text { persons I enjoy. }\end{array}$ & $\begin{array}{l}\text { I enjoy exercise. } \\
\text { Exercise improves my men- } \\
\text { tal health. } \\
\text { Exercise decreases feel- } \\
\text { ings of stress and tension } \\
\text { for me. }\end{array}$ \\
\hline
\end{tabular}

Figure 3.

Benefit differences by disability group. *Tied items.

erature. Many individuals with MD regress functionally despite involvement in exercise; these participants may have focused primarily on the social benefits of a team sport. In contrast, some participants with $\mathrm{CP}$ might have had functional improvement from exercise and wanted to continue improving physical performance through sport. Persons with other physical disabilities reported strictly psychological benefits (Figure 3). Again, it is not unusual for persons with physical disabilities to perceive affective benefits from exercise, but it is unique that this group reported this factor to the exclusion of other possible benefits.

\section{Exercise Barriers}

Despite the multitude of barriers reported in the literature for people with physical disabilities, the current cohort reported three consistent barriers, namely "Exercise is hard work for me," "Exercise tires me," and "There are too few places to exercise." Given the limited functional capacity of participants, it was not surprising to identify "physical exertion" items as primary barriers to exercise. Physical exertion was first used by Sechrist et al. [31] and is consistent with "lack of energy" barriers reported for multiple populations, including those with $[29,36,41-42]$ and without $[32,37]$ physical disabilities. Limited places to exercise is also consistent with literature for adults and children with physical disabilities $[36,43]$ and young adults without disabilities [32]. Interestingly, for the group as a whole, exercise cost and social support were not identified as primary barriers despite the increased cost and dependence on others required for them to access activity settings. Our cohort might have already overcome these barriers, given that they were already active sport participants. In essence, cost and social support may have been barriers at one point, but the participants seemed to have overcome them and no longer perceived access as a major barrier to regu- lar exercise. This finding is an important distinction to barriers reported for persons with disabilities in general.

\section{Study Limitations}

Two limitations to the current study deserve attention. First, study participants were a small convenience sample rather than a large random sample. To better understand exercise perceptions, researchers should recruit many participants randomly from a national representative sample. However, small numbers of disability sport participants make recruitment, randomization, and analysis difficult [44]. Nonsignificant differences between groups could reflect insufficient power due to the small sample size. We did use nonparametric tests to control for limited statistical power, but sample size should still be considered for specific demographic groups. Second, power wheelchair soccer players are not necessarily representative of all power wheelchair users. The sample was limited to power soccer competitors because of the need to examine benefits and barriers in a specific homogenous group. Because persons with physical disabilities want to incorporate exercise into their lifestyle $[42,45-46]$, we felt it was important to examine participants who had had exposure to exercise and who could address both benefits and barriers. The stage of exercise change can affect perception, and our cohort likely represents a higher percentage of regular exercisers than most power wheelchair users.

\section{CONCLUSIONS}

In a group of power wheelchair soccer players, perceived benefits of exercise are influenced by disability type. Participants did report one environmental influence, the ability to have contact with friends, but most perceived benefits were primarily personal rather than environmental. 
Physical exertion and access to facilities were the primary barriers to exercise, and this finding is consistent in higherfunctioning groups with physical disabilities.

\section{ACKNOWLEDGMENTS}

\author{
Author Contributions: \\ Study concept and design: J. P. Barfield, L. A. Malone. \\ Acquisition of data: J. P. Barfield. \\ Analysis and interpretation of data: J. P. Barfield, L. A. Malone. \\ Drafting of manuscript: J. P. Barfield, L. A. Malone. \\ Critical revision of manuscript for important intellectual content: \\ J. P. Barfield, L. A. Malone. \\ Statistical analysis: J. P. Barfield, L. A. Malone. \\ Administrative, technical, or material support: J. P. Barfield. \\ Study supervision: J. P. Barfield.
}

Financial Disclosures: The authors have declared that no conflict of interest with any wheelchair sport or therapeutic recreation provider exists.

Funding/Support: This material was unfunded at the time of manuscript preparation. Dr. Barfield is now with the School of Sport Science, Endicott College, Beverly, Massachusetts.

Institutional Review: The Emory and Henry College Institutional Review Board approved the study before it began, and all participants provided informed consent.

Participant Follow-Up: The authors will notify coaches and program supervisors of participants when the research is published. The authors did not collect personal contact information from participants but will be able to notify individuals indirectly through coaches and supervisors.

\section{REFERENCES}

1. U.S. Department of Health and Human Services. Healthy people 2010: Understanding and improving health. 2nd ed. Washington (DC): U.S. Government Printing Office; 2000.

2. Bodde AE, Seo DC. A review of social and environmental barriers to physical activity for adults with intellectual disabilities. Disabil Health J. 2009;2(2):57-66.

[PMID:21122744]

http://dx.doi.org/10.1016/j.dhjo.2008.11.004

3. Centers for Disease Control and Prevention (CDC). Physical activity among adults with a disability - United States, 2005. MMWR Morb Mortal Wkly Rep. 2007;56(39): 1021-24. [PMID:17914329]

4. Disability and Health-Healthy People 2020 [Internet]. Washington (DC): U.S. Department of Health and Human Services; 2012 Feb 8 [cited 2012 Apr 2].

Available from: http://www.healthypeople.gov/2020/ topicsobjectives2020/overview.aspx?topicid $=9$.
5. Gil-Agudo A, Del Ama-Espinosa A, Crespo-Ruiz B. Wheelchair basketball quantification. Phys Med Rehabil Clin N Am. 2010;21(1):141-56. [PMID:19951783] http://dx.doi.org/10.1016/j.pmr.2009.07.002

6. van Langeveld SA, Post MW, van Asbeck FW, ter Horst P, Leenders J, Postma K, Rijken H, Lindeman E. Contents of physical therapy, occupational therapy, and sports therapy sessions for patients with a spinal cord injury in three Dutch rehabilitation centres. Disabil Rehabil. 2011;33(5): 412-22. [PMID:20604689] http://dx.doi.org/10.3109/09638288.2010.498548

7. Vlak T, Padjen I, Pivalica D. Paralympians-unknown heroes next door. Croat Med J. 2009;50(6):527-30. [PMID:20017218] http://dx.doi.org/10.3325/cmj.2009.50.527

8. Di Russo F, Bultrini A, Brunelli S, Delussu AS, Polidori L, Taddei F, Traballesi M, Spinelli D. Benefits of sports participation for executive function in disabled athletes. J Neurotrauma. 2010;27(12):2309-19. [PMID:20925480] http://dx.doi.org/10.1089/neu.2010.1501

9. Giacobbi PR Jr, Stancil M, Hardin B, Bryant L. Physical activity and quality of life experienced by highly active individuals with physical disabilities. Adapt Phys Activ Q. 2008;25(3):189-207. [PMID:18765861]

10. Goosey-Tolfrey V, Castle P, Webborn N, Abel T. Aerobic capacity and peak power output of elite quadriplegic games players. Br J Sports Med. 2006;40(8):684-87.

[PMID:16611721]

http://dx.doi.org/10.1136/bjsm.2006.026815

11. Morgulec N, Kosmol A, Molik B, Hubner-Wozniak E, Rutkowska I. The effect of training on aerobic performance in wheelchair rugby players. Res Yearbook Stud Phys Ed Sport. 2006;12:195-98.

12. Shiba S, Okawa H, Uenishi H, Koike Y, Yamauchi K, Asayama K, Nakamura T, Tajima F. Longitudinal changes in physical capacity over 20 years in athletes with spinal cord injury. Arch Phys Med Rehabil. 2010;91(8):1262-66. [PMID:20684908] http://dx.doi.org/10.1016/j.apmr.2010.04.024

13. Furmaniuk L, Cywińska-Wasilewska G, Kaczmarek D. Influence of long-term wheelchair rugby training on the functional abilities in persons with tetraplegia over a twoyear post-spinal cord injury. J Rehabil Med. 2010;42(7): 688-90. [PMID:20603700] http://dx.doi.org/10.2340/16501977-0580

14. Sporner ML, Fitzgerald SG, Dicianno BE, Collins DM, Teodorski E, Pasquina PF, Cooper RA. Psychosocial impact of participation in the National Veterans Wheelchair Games and Winter Sports Clinic. Disabil Rehabil. 2009; 31(5):410-18. [PMID:18608391] http://dx.doi.org/10.1080/09638280802030923 
15. Abel T, Platen P, Rojas Vega S, Schneider S, Strüder HK. Energy expenditure in ball games for wheelchair users. Spinal Cord. 2008;46(12):785-90. [PMID:18521095] http://dx.doi.org/10.1038/sc.2008.54

16. Roy JL, Menear KS, Schmid MM, Hunter GR, Malone LA. Physiological responses of skilled players during a competitive wheelchair tennis match. J Strength Cond Res. 2006; 20(3):665-71. [PMID:16977715]

17. Barfield JP, Malone LA, Arbo C, Jung AP. Exercise intensity during wheelchair rugby training. J Sports Sci. 2010; 28(4):389-98. [PMID:20131143] http://dx.doi.org/10.1080/02640410903508839

18. Sporner ML, Grindle GG, Kelleher A, Teodorski EE, Cooper R, Cooper RA. Quantification of activity during wheelchair basketball and rugby at the National Veterans Wheelchair Games: A pilot study. Prosthet Orthot Int. 2009;33(3):210-17. [PMID:19658011] http://dx.doi.org/10.1080/03093640903051816

19. Anneken V, Hanssen-Doose A, Hirschfeld S, Scheuer T, Thietje R. Influence of physical exercise on quality of life in individuals with spinal cord injury. Spinal Cord. 2010;48(5):393-99. [PMID:19841634] http://dx.doi.org/10.1038/sc.2009.137

20. McVeigh SA, Hitzig SL, Craven BC. Influence of sport participation on community integration and quality of life: a comparison between sport participants and non-sport participants with spinal cord injury. J Spinal Cord Med. 2009; 32(2):115-24. [PMID:19569458]

21. Martin JJ. Multidimensional self-efficacy and affect in wheelchair basketball players. Adapt Phys Activ Q. 2008; 25(4):275-88. [PMID:18955745]

22. Kumar A, Karmarkar AM, Collins DM, Souza A, Oyster ML, Cooper RC, Cooper RA. Pilot study for quantifying driving characteristics during power wheelchair soccer. J Rehabil Res Dev. 2012;49(1):75-82. [PMID:22492339] http://dx.doi.org/10.1682/JRRD.2010.09.0191

23. Karmarkar AM, Collins DM, Wichman T, Franklin A, Fitzgerald SG, Dicianno BE, Pasquina PF, Cooper RA. Prosthesis and wheelchair use in veterans with lower-limb amputation. J Rehabil Res Dev. 2009;46(5):567-76. [PMID:19882491] http://dx.doi.org/10.1682/JRRD.2008.08.0102

24. National Disability Sports Alliance. Power soccer-start a team now. Palaestra. 2009;24(3):17.

25. Barfield JP, Malone LA, Collins JM, Ruble SB. Disability type influences heart rate response during power wheelchair sport. Med Sci Sports Exerc. 2005;37(5):718-23. [PMID:15870623] http://dx.doi.org/10.1249/01.MSS.0000161807.77552.8B

26. Kerstin W, Gabriele B, Richard L. What promotes physical activity after spinal cord injury? An interview study from a patient perspective. Disabil Rehabil. 2006;28(8):481-88.

\section{[PMID:16513581]}

http://dx.doi.org/10.1080/09638280500211932

27. Martin Ginis KA, Latimer AE, Buchholz AC, Bray SR, Craven BC, Hayes KC, Hicks AL, McColl MA, Potter PJ, Smith K, Wolfe DL. Establishing evidence-based physical activity guidelines: methods for the Study of Health and Activity in People with Spinal Cord Injury (SHAPE SCI). Spinal Cord. 2008;46(3):216-21. [PMID:17646838] http://dx.doi.org/10.1038/sj.sc.3102103

28. Rimmer JH, Chen MD, McCubbin JA, Drum C, Peterson J. Exercise intervention research on persons with disabilities: what we know and where we need to go. Am J Phys Med Rehabil. 2010;89(3):249-63. [PMID:20068432] http://dx.doi.org/10.1097/PHM.0b013e3181c9fa9d

29. Scelza WM, Kalpakjian CZ, Zemper ED, Tate DG. Perceived barriers to exercise in people with spinal cord injury. Am J Phys Med Rehabil. 2005;84(8):576-83.

[PMID:16034226] http://dx.doi.org/10.1097/01.phm.0000171172.96290.67

30. Levins SM, Redenbach DM, Dyck I. Individual and societal influences on participation in physical activity following spinal cord injury: a qualitative study. Phys Ther. 2004;84(6):496-509. [PMID:15161416]

31. Sechrist KR, Walker SN, Pender NJ. Development and psychometric evaluation of the exercise benefits/barriers scale. Res Nurs Health. 1987;10(6):357-65. [PMID:3423307] http://dx.doi.org/10.1002/nur.4770100603

32. Brown DJ, DeCorse-Johnson AL, Irving-Ray M, Wu WW. Performance evaluation for diversity programs. Policy Polit Nurs Pract. 2005;6(4):331-34. [PMID:16443988] http://dx.doi.org/10.1177/1527154405283380

33. Kehn M, Kroll T. Staying physically active after spinal cord injury: a qualitative exploration of barriers and facilitators to exercise participation. BMC Public Health. 2009;9:168. [PMID:19486521]

http://dx.doi.org/10.1186/1471-2458-9-168

34. Vissers M, van den Berg-Emons RJ, Sluis T, Bergen M, Stam H, Bussmann H. Barriers to and facilitators of everyday physical activity in persons with a spinal cord injury after discharge from the rehabilitation centre. J Rehabil Med. 2008;40(6):461-67. [PMID:18509562] http://dx.doi.org/10.2340/16501977-0191

35. Driver S. Social support and the physical activity behaviours of people with a brain injury. Brain Inj. 2005; 19(13):1067-75. [PMID:16286320]

36. Buffart LM, Westendorp T, van den Berg-Emons RJ, Stam HJ, Roebroeck ME. Perceived barriers to and facilitators of physical activity in young adults with childhood-onset physical disabilities. J Rehabil Med. 2009;41(11):881-85. [PMID: 19841838] http://dx.doi.org/10.2340/16501977-0420 
37. Williams BR, Bezner J, Chesbro SB, Leavitt R. The effect of a walking program on perceived benefits and barriers to exercise in postmenopausal African American women. J Geriatr Phys Ther. 2006;29(2):43-49. [PMID:16914065]

38. Kinne S, Patrick DL, Maher EJ. Correlates of exercise maintenance among people with mobility impairments. Disabil Rehabil. 1999;21(1):15-22. [PMID:10070599] http://dx.doi.org/10.1080/096382899298052

39. Cardinal BJ, Kosma M, McCubbin JA. Factors influencing the exercise behavior of adults with physical disabilities. Med Sci Sports Exerc. 2004;36(5):868-75. [PMID:15126723] http://dx.doi.org/10.1249/01.MSS.0000126568.63402.22

40. Furst DM, Ferr T, Megginson N. Motivation of disabled athletes to participate in triathlons. Psychol Rep. 1993; 72(2):403-6. [PMID:8488223] http://dx.doi.org/10.2466/pr0.1993.72.2.403

41. Odette F, Yoshida KK, Israel P, Li A, Ullman D, Colontonio A, Maclean H, Locker D. Barriers to wellness activities for Canadian women with physical disabilities. Health Care Women Int. 2003;24(2):125-34. [PMID:12746022]

42. Rimmer JH, Rubin SS, Braddock D. Barriers to exercise in African American women with physical disabilities. Arch Phys Med Rehabil. 2000;81(2):182-88. [PMID:10668772]

43. Johnson CC. The benefits of physical activity for youth with developmental disabilities: a systematic review. Am J Health Promot. 2009;23(3):157-67. [PMID:19149420] http://dx.doi.org/10.4278/ajhp.070930103

44. Croft L, Dybrus S, Lenton J, Goosey-Tolfrey V. A comparison of the physiological demands of wheelchair basketball and wheelchair tennis. Int J Sports Physiol Perform. 2010; 5(3):301-15. [PMID:20861521]

45. Rimmer JH, Riley B, Wang E, Rauworth A, Jurkowski J. Physical activity participation among persons with disabilities: barriers and facilitators. Am J Prev Med. 2004;26(5): 419-25. [PMID:15165658] http://dx.doi.org/10.1016/j.amepre.2004.02.002

46. Malone LA, Barfield JP, Brasher JD, Perceived benefits and barriers to exercise among persons with physical disabilities or chronic health conditions within action or maintenance stages of exercise. Disabil Health J. 2012;5(4): 254-60. [PMID:23021736] http://dx.doi.org/10.1016/j.dhjo.2012.05.004

Submitted for publication December 8, 2011. Accepted in revised form June 25, 2012.

This article and any supplemental material should be cited as follows:

Barfield JP, Malone LA. Perceived exercise benefits and barriers among power wheelchair soccer players. J Rehabil Res Dev. 2013;50(2):231-38.

http://dx.doi.org/10.1682/JRRD.2011.12.0234

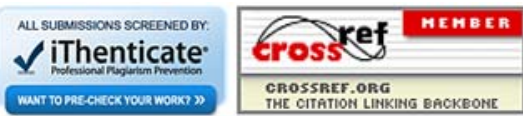

